\title{
ONESNAŽEVANJE GORSKIH JEZER
}

\begin{abstract}
Anton Brancelj"
Izvleček

UDK 504.4.054(285.2)

Za gorska jezera $v$ Sloveniji je dolgo časa veljalo, da niso izpostavljena onesnaževanju tako kot nižinska jezera. Podrobnejše raziskave v zadnjem desetletju pa so pokazale, da je vpliv človeka močan tudi v tako oddaljenih predelih. Gorska jezera pri nas ogroža turizem, prenos škodljivih snovi po zraku ter naseljevanje rib. $V$ treh jezerih so bile opravljene tudi analize sedimenta, $s$ katerimi so se ovrednotili vnosi nekaterih snovi v jezera $v$ preteklih desetletjih.
\end{abstract}

Ključne besede: gorska jezera, onesnaževanje, sediment, evtrofizacija, Slovenija,

MOUNTAIN LAKE POLLUTION

\section{Abstract}

Mountain lakes in Slovenia were considered for a long time as pristine, unpolluted lakes, in opposite to most of low-land lakes. Analyses in the last decade revealed considerable human impact even in such remote places. Lakes are threatened by tourism, long-distance transport of pollutants and fish introduction. In three selected lakes analyses of the sediment were done to evaluate input of some pollutants in the last few decades.

Key words: mountain lakes, pollution, sediment, eutrophication, Slovenia

\footnotetext{
* Dr., doc., Nacionalni inštitut za biologijo; Večna pot 111; 1000 Ljubljana, Slovenija
} 


\section{UVOD}

V Sloveniji imamo v primerjavi s sosednjimi državami (Italija in Avstrija) razmeroma malo gorskih oz. visokogorskih jezer. Ta jezera so v Sloveniji le v Triglavskem narodnem parku. Vzrok za majhno število jezer je treba iskati v neugodni geološki podlagi, saj v Julijskih Alpah prevladujejo močno zakraseli dahštajnski apnenci. Le na nekaterih mestih so se ustvarile ugodne razmere (neprepustni jurski skladi), ki omogočajo, da so se na zakraseli podlagi oblikovale jezerske kadunje. Tako je bil omogočen nastanek bolj ali manj plitvih in tudi različno velikih jezer. $\mathrm{O}$ veliki zakraselosti okolice jezer govori tudi podatek, da smo doslej kar za šest jezer ugotovili, da odtekajo neposredno v požiralnike, ki so sicer zasuti z gruščem.

Glede na zemljepisno lego jih lahko razdelimo nekako v tri skupine. Najbolj enotna je t.i. kriška skupina jezer, ki obsega Zgornje, Srednje in Spodnje Kriško jezero. Značilno zanje je, da vsa ležijo nad gozdno oz. drevesno mejo, so bolj ali manj okrogle oblike in razmeroma globoka. Po podatkih Gamsa (1962) in lastnih meritvah so globoka med 6 in $10 \mathrm{~m}$ (tabela 1). Najbolj heterogeno skupino predstavlja t.i. krnska skupina, v kateri so tri jezera. Največje in najgloblje nasploh v naših gorah je Krnsko jezero. V njegovi neposredni bližini je plitvo in majhno Dupeljsko jezero (tudi Jezero pod Monturo). Obe jezeri ležita pod gozdno mejo. Najbolj oddaljeno in razmeroma malo poznano pa je Jezero v Lužnici, ki leži nad gozdno mejo. Najbolj poznana je skupina jezer v Dolini sedmerih jezer, h katerim iz praktičnih razlogov prištevam tudi Jezero na Planini pri Jezeru. Zgornja jezera $\mathrm{v}$ tej dolini (Jezero $\mathrm{v}$ Ledvici, Rjavo, Zeleno ter Jezero pod Vršakom) se nahajajo nad gozdno mejo.

Vsa tri Kriška jezera in Jezero v Lužnici ležijo v zahodnem delu Julijskih Alp in so tako neposredno izpostavljena zahodnim vetrovom. Delno to velja tudi za Jezero pod Vršakom in Rjavo jezero, ki sicer že ležita za grebenom med Vršakom nad Zadnjico in Malim ter Velikim Špičjem. Vsa ostala jezera so bolj pod vplivom vzhodnih oz. jugovzhodnih vetrov.

Čeprav so vsa jezera, mogoče z izjemo Jezera v Lužnici, razmeroma dobro poznana in tudi lahko dostopna, pa je o njih presenetljivo malo znanega. Pravzaprav je ena od redkih celovitih študij o njih že prej omenjeni članek Gamsa (1962), v kateri je objavil tudi morfometrične meritve vseh jezer. Tudi z biološkega vidika so bile prve celovite študije rastlinstva in živalstva, pa tudi kemijskih ter fizikalnih lastnosti vode v nekaterih jezerih opravljene šele konec osemdesetih oziroma v začetku devetdesetih let. Do takrat je veljalo, da so vode $\mathrm{v}$ teh gorskih in visokogorskih jezerih še pravi biseri. Podrobnejše raziskave pa so pokazale, da je stanje jezer precej bolj zaskrbljujoče.

Že od osemdesetih let dalje se je govorilo o kislem dežju, ki povzroča poškodbe v obliki ožigov na rastlinju (Batič, 1996), pa o povišanih količinah radioaktivnih snovi 
$\mathrm{v}$ prsti ali celo v lišajih ter gobah (Jeran in sod., 1991). Vse te meritve in raziskave so zaobšle visokogorska jezera, čeprav se je pokazalo, da so v nekaterih primerih celo bolj uporabna za analizo stanja okolja kot zrak ali prst.

Posledice kislega dežja na delovanje jezerskih sistemov so zaradi posebne geološke sestave bolj prikrite. Voda $\mathrm{v}$ samih jezerih je namreč tako močno nasičena $\mathrm{s}$ karbonati, da ti takoj nevtralizirajo učinek kislega dežja. Tudi ti učinki se do neke mere kažejo v še ne dovolj dobro pojasnjeni povečani sedimentaciji.

O drugih posegih, ki vplivajo na kakovost vode in življenjskih združb v jezerih, torej na onesnaževanje vodnega okolja, pa bo govora v nadaljevanju.

\section{RAZISKAVE GORSKIH JEZER V LETIH 1990-1998}

Do začetka devetdesetih let je bilo na slovenskih gorskih jezerih opravljenih le malo raziskav. Prve sistematične raziskave kakovosti vod v jezerih so se začele šele v letu 1990, ko so sodelavci takratnega Inštituta za biologijo opravili prve kemijske, fizikalne in biološke analize v jezerih v Dolini sedmerih jezer (Bricelj in sod., 1991). To je bilo opravljeno na podlagi t.i. presejalnega monitoringa jezer $\mathrm{v}$ Triglavskem narodnem parku, ki ga je podprlo tedanje Ministrstvo za varstvo okolja. Kasneje so se raziskave nadaljevale ob podpori Ministrstva za znanost in tehnologijo in tudi Evropske zveze. Logistično podporo pa je nudil Triglavski narodni park.

Nacionalni projekt, v katerem smo se prvič lotili problematike triglavskih jezer, je bil projekt "Katalog limnoflore in limnofavne Slovenije". Cilj tega projekta je bil sestaviti kar najbolj popoln seznam rastlinstva in živalstva tudi $\mathrm{v}$ gorskih in visokogorskih jezerih (Brancelj in sod., 1995, 1997). Vzporedno z nacionalnim projektom je potekal v obdobju 1994-1995 še evropski projekt AL:PE2 (Wathne in sod., 1996), katerega namen je bil izmeriti stopnjo onesnaževanja iz zraka. Posebna pozornost je bila namenjena vplivu kislega dežja na jezerske ekosisteme, ostankom izgorelih naftnih derivatov iz prometa in industrije, pa tudi koncentraciji radioaktivnih delcev kot posledic jedrskih poskusov v zraku v šestdesetih letih ter černobilske jedrske nesreče $\mathrm{v}$ osemdesetih letih. Kot vzorčni primer je bilo $\mathrm{v}$ Sloveniji izbrano Zgornje Kriško jezero. To je naše najvišje ležeče jezero in zato, vsaj teoretično, tudi najbolj čisto. $\mathrm{V}$ tem jezeru so bili odvzeti tudi vzorci jezerskega sedimenta. Njihova analiza naj bi razkrila dogajanja $\mathrm{v}$ jezeru in njegovi okolici $\mathrm{v}$ zadnjih nekaj desetletjih.

Leta 1996 se je začel nacionalni projekt SLO-Alpe, katerega namen je bil ugotoviti obseg različnih vrst onesnaženja, še zlasti pa procesov antropogene evtrofizacije (Brancelj in sod., 1998). Posebna pozornost je bila namenjena trem izbranim jezerom, 
ki so kazala različno stopnjo evtrofizacije. Kot najbolj čisto (= oligotrofno) jezero je bilo izbrano Jezero v Ledvicah, zgled za mezotrofno jezero je bilo Krnsko jezero in kot primer za s hranili najbolj obremenjeno jezero je bilo Jezero na Planini pri Jezeru.

Hkrati s tem projektom se je začel tudi evropski projet, t.i. MOLAR (Mountain Lake Research: Measuring and modelling the dynamic response of remote lake ecosystems to environmental change). Slovenski sodelavci smo poskušali na zgledu Jezera $\mathrm{v}$ Ledvicah oceniti posledice onesnaženja nanj $\mathrm{v}$ zadnjih dveh stoletjih, intenzivnost vnašanja onesnaževalcev $\mathrm{v}$ jezero ter odzive rastlinstva in živalstva na spremembo podnebja v zadnjih dveh stoletjih.

\section{MATERIAL IN METODE}

Vzorce za fizikalne in kemijske meritve oz. analize smo jemali na sredini jezera oz. na najglobji točki. Običajno smo jemali v 2,5 oz. 5 metrskem intervalu od površine do dna. Na vseh jezerih, razen na Jezeru v Ledvici, Krnskem jezeru ter Jezeru na Planini pri Jezeru, smo jemali vzorce le ob koncu turistične sezone (konec avgusta ali začetek septembra). Navedena tri jezera pa so bila vzorčena pogosteje, praviloma v mesečnih intervalih v obdobju brez ledu. Vse analize so potekale po priporočilih APHA (1985). V skladu z omenjenimi priporočili so bili vzeti tudi vzorci za biološke analize: določanje biomase zooplanktona ter koncentracije zelenega rastlinskega barvila (klorofila).

Vzorce za analizo sedimeta smo odvzeli z gravitacijskim vzorčevalnikom (prirejeni tip Kajak) s premerom cevi $6 \mathrm{~cm}$ in dolžino $66 \mathrm{~cm}$. Vzorce sedimenta smo navadno že na obali razrezali na $0,5 \mathrm{~cm}$ debele rezine (od $0-10 \mathrm{~cm}$ globine) $\mathrm{oz}$. na $1 \mathrm{~cm}$ debele rezine (ostanek vzorca). Od vsake rezine smo za določanje starosti s pomočjo meritev koncentracij svinčevega izotopa $\mathrm{Pb}^{210}$ ter cezijevih izotopov $\mathrm{Cs}^{137}$ oz. $\mathrm{Cs}^{134}$ odvzeli del sedimenta. Te meritve so opravili na Institutu Jožef Stefan. Del vzorca smo porabili za določanje t.i.kroglastih ogljikovih ostankov fosilnih goriv (SCP sphaeroidal carbonaceous particles), ostali del pa smo porabili za analizo ostankov vodnih bolh ter kremenastih alg (diatomej).

V vsako od treh izbranih jezer smo takoj po odtalitvi ledu v letu 1996 potopili tudi sedimentacijske pasti (4 cevi premera $7,5 \mathrm{~cm}$ in dolžine $50 \mathrm{~cm}$ ) v katere smo lovili vse, kar se je sedimentiralo iz vodnega stolpca na najgloblji točki jezer. Pasti smo v obdobju brez ledu praznili v približno mesečnih razmakih in kasneje njihovo vsebino v laboratoriju analizirali. 


\section{REZULTATI IN DISKUSIJA}

Že na začetku raziskav so analize pokazale, da se jezera med seboj ločijo po celi vrsti parametrov (fizikalnih, kemijskih in bioloških). Del teh razlik gre pripisati njihovi naravni legi (nadmorska višina, vegetacija, ekspozicija, morfometrične značilnosti jezer). Drugi del razlik pa je posledica človekove dejavnosti bodisi v neposredni okolici jezer ali pa tudi $\mathrm{v}$ širšem območju. Človekove dejavnosti, ki posredno ali neposredno vplivajo na kakovost vode $v$ naših gorskih jezerih, delimo $v$ tri skupine:
a) vnašanje strupenih in škodljivih snovi
b) vnašanje hranilnih snovi (dušikove in fosforjeve spojine)
c) poseganje v vrstno sestavo jezerskih združb (biocenoz).

Strupene in škodljive snovi se $\mathrm{v}$ gorska jezera lahko vnašajo neposredno $\mathrm{z}$ izlivanjem oz. odlaganjem. Zaradi dobre obveščenosti in zavesti ljudi je tovrstnih vplivov vse manj. V preteklosti, ko se ljudje še niso toliko zavedali posledic, je bilo tega nekoliko več. Vendar pa so bile posledice dokaj omejene, tako časovno kot prostorsko. Edini tovrstni poseg, za katerega lahko z veliko gotovostjo trdimo, da je imel večje posledice na jezero, je bila obnova doma na Planini pri Jezeru. Pri analizi sedimenta smo namreč ugotovili, da se je $\mathrm{v}$ globini $4 \mathrm{~cm}$ sestava ostankov planktonskih in bentoških organizmov nenadoma za kratek čas močno spremenila. Prevladovalo je le nekaj vrst, ki so sicer značilne za močno onesnažena jezera. Datacija s pomočjo svinčevega izotopa ${ }^{210} \mathrm{~Pb}$ je pokazala, da se je to zgodilo v drugi polovici osemdesetih let. Verjetno je med obnovitvenimi deli odtekala $\mathrm{v}$ jezero voda, pomešana ne samo s cementom in apnom, ampak tudi z organskimi odpadki. Od tedaj najprej pa se stanje $\mathrm{v}$ jezeru počasi izboljšuje, vsaj kar se tiče sestave vodnega rastlinstva in živalstva.

Veliko večji obseg ima onesnaževanje na velike razdalje, ki se širi z vetrom in padavinami. Med tovrstne snovi spadajo različni oksidi (zlasti dušikovi in žveplovi), ki povzročajo na nekarbonatnih tleh zakisovanje vode (Wathne, 1992). V sedimentu se tako onesnaževanje kaže kot koncentracija kroglastih ogljikovih delcev, ki so ostanki zgorevanja fosilnih goriv (nafte in premoga). V Sloveniji so bile tovrstne analize doslej opravljene $\mathrm{v}$ sedimentu Zgornjega Kriškega jezera ter Jezera $\mathrm{v}$ Ledvicah. Primerjava $\mathrm{z}$ ostalimi gorskimi jezeri v Evropi je pokazala, da prejmejo naša jezera zelo visoke deleže tega onesnaženja (Brancelj, 1995, Grimault in sod., 1997). Tudi meritve, ki smo jih opravili v sedimentacijskih pasteh v letih 1996 in 1997, kažejo, da so te koncentracije razmeroma visoke, saj kumulativne vrednosti dosegajo po nekaj 100 delcev na kvadratni centimeter na leto (slika 1) (Gaberščik in sod., 1997; Urbanc-Berčič in sod., 1998), njihov delež pa se iz leta v leto spreminja. Del tovrstnega onesnaževanja gre pripisati tudi uporabi agregatov za proizvodnjo električne energije za koče $v$ našem visokogorju. Ker pa je veliko koč $\mathrm{v}$ zadnjih dveh letih prešlo na oskrbo s sončnimi celicami in akumulatorji, pričakujemo delno zmanjševanje deleža kroglastih ogljikovih delcev v zraku. 
Drugi tip škodljivih oz. nevarnih snovi, ki so prispela $\mathrm{v}$ gorska jezera $\mathrm{z}$ vetrom pa so radioaktivni delci. Ti so posledica eksplozij jedrskih bomb v zraku (sredi šestdesetih let) ter černobilske eksplozije (v osemdesetih letih). Ob ugotavljanju starosti sedimentov v Zgornjem Kriškem in Krnskem jezeru, Jezeru v Ledvicah in v Jezeru na Planini pri Jezeru se je pokazalo, da so koncentracije cezijevih izotopov $\left(\mathrm{Cs}^{134}\right.$, Cs ${ }^{137}$ ) in americijevega izotopa $\left(\mathrm{Am}^{241}\right)$ med najvišjimi v opazovanih gorskih jezerih po Evropi (Grimault in sod., 1997). V naših jezerih so največje koncentracije cezija in americija danes v sedimentu Jezera v Ledvici na globini $1,5 \mathrm{~cm}$, oz. na globini $4 \mathrm{~cm} \mathrm{v}$ Jezeru na Planini pri Jezeru (Brancelj in sod., 1998), kar je odvisno od količine sedimentiranih snovi v zadnjem desetletju.

Hranilne snovi, kamor v prvi vrsti spadajo fosforjeve in dušikove spojine, vplivajo na procese evtrofizacije jezer. Del teh snovi se $\mathrm{v}$ procesu mineralizacije počasi izloča $\mathrm{v}$ jezero tudi $\mathrm{v}$ naravnem kroženju snovi, vendar je ta del majhen $\mathrm{v}$ primerjavi $\mathrm{s}$ tistim, ki ga povzroča človek. Glavni viri tovrstnih vnosov so turistični objekti na območju jezer in pašništvo. Pri turističnih objektih so glavni viri odplake iz kuhinj in stranišč. Z ureditvijo stranišč (preusmeritev iztoka, suha stranišča) oz. zmanjševanjem pranja se je tudi tovrstno onesnaževanje precej zmanjšalo. Kljub temu pa so v jezerih še vedno razmeroma velike koncentracije hranil, kar se kaže zlasti v povečani količini alg (tabela 2). Povečane koncentracije zasledimo zlasti pri jezerih, ki ležijo pod gozdno mejo in v bližini pomembnejših turističnih poti. Med takšna jezera spadajo Jezero na Planini pri Jezeru, Krnsko jezero, Črno jezero in Spodnje Kriško jezero. Tudi obremenjenost $\mathrm{s}$ hranili upada $\mathrm{v}$ navedenem vrstnem redu. Od tega odstopa Dvojno jezero, ki leži v neposredni bližini koče, vendar je v tem primeru hidrologija oz. geologija taka, da odpadne vode (zlasti iz sanitarij) praviloma odtekajo $\mathrm{v}$ podlago mimo jezera. Zaradi zmanjševanja pašništva je tovrstna problematika vse bolj zanemarljiva, čeprav je imela v preteklosti večji vpliv.

Povečane količine hranilnih snovi $\mathrm{v}$ jezerih se najprej kažeko $\mathrm{v}$ povečani primarni in sekundarni produkciji, t.j. v povečani količini alg in planktonskih živali. Tudi na dnu se začno pojavljati alge, zlasti nitaste zelene alge. Ko začnejo te alge odmirati, se pri njihovi razgradnji porablja kisik, tako da $\mathrm{v}$ globljih plasteh jezera pride do hipoksij ali celo anoksij (popolna odsotnost raztopljenega kisika). To je še zlasto očitno v času poletne in tudi zimske plastovitosti jezer. Najbolj kritičen primer je Jezero na Planini pri Jezeru, kjer prihaja do popolnih anoksij, redno ob koncu poletja in zgodaj spomladi. Rezultat je popolna odsotnost živali na jezerskem dnu, kar je posledica močno povečanih koncentracij amonijaka in žveplovodika $v$ globinah, večjih od $5 \mathrm{~m}$. Podobne, vendar nekoliko manj kritične razmere, smo v zadnjih dveh letih opazovali tudi $\mathrm{v}$ Krnskem jezeru. Tam so bile koncentracije kisika, tudi $\mathrm{v}$ najbolj kritičnem obdobju, še vedno okoli 10 odstotne. V Jezeru na Planini pri Jezeru pa v istem obdobju nismo mogli ugotoviti prisotnosti kisika. V drugih jezerih, npr. v Jezeru $\mathrm{v}$ 
Ledvici smo izmerili najnižje koncentracije kisika tik po stalitvi ledu, vendar so tudi takrat še vedno znašale okoli 40-50 \% nasičenosti.

Vnašanje rib je poseben vidik izredno negativnega poseganja človeka $\mathrm{v}$ občutljive ekosisteme gorskih jezer. Nobeno od naših gorskih jezer ni bilo poseljeno z ribami po naravni poti, temveč jih je tja zanesel človek. Tako je za Krnsko jezero znano, da so ga naselili $\mathrm{z}$ ribami $\mathrm{v}$ dvajsetih letih tega stoletja, Jezero na Planini pri Jezeru $\mathrm{v}$ petdesetih letih, Dvojno jezero pa v devetdesetih letih. Naseljevali so tudi Dupeljsko in Črno jezero, vendar so bili pri tem manj uspešni. Razlogi za naseljevanje so bili različni (kot popestritev prehrane - Jezero na Planini pri Jezeru; športni ribolov Krnsko jezero in verjetno tudi Dvojno jezero). Posledice na omenjena jezera pa so bile katastrofalne (Brancelj, 1997). Ribe so $\mathrm{v}$ naštetih jezerih povsem porušile naravno ravnovesje, zlasti so negativno vplivale na prehranjevalne verige. Prišlo je tudi do pospešene evtrofizacije jezer. Za Jezero na Planini pri Jezeru, kjer prevladuje koreselj, je bila za jezero usodna njegova prehranjevalna navada. Mladiči koreslja se hranijo s planktonskimi rakci, ki sicer omejujejo količino planktonskih alg, odrasle ribe pa se hranijo na dnu, pri čemer dvigujejo $\mathrm{z}$ dna sediment, bogat $\mathrm{s}$ hranilnimi snovmi, ki tako prihajajo $\mathrm{v}$ vodni stolpec. Tako povzročajo pospešeno evtrofizacijo. Povečana količina alg $\mathrm{v}$ vodi, $\mathrm{z}$ vsemi negativnimi posledicami, še stopnjuje visok turistični obisk in njegove posledice v obliki izpustov. Podoben primer je tudi Krnsko jezero. Pisanci, ki so sicer najbolj številčne ribe $\mathrm{v}$ jezeru, ne brskajo toliko po sedimentu in zato je vračanje hranilnih snovi iz sedimenta $v$ vodni stolpec nekoliko manjša.

Na Dvojnem jezeru smo spremljali uničenje jezerskega ekosistema tako rekoč "iz prve vrste parterja". Merili smo številne parametre, ki vplivajo na kakovost vode, in ugotovili, da je v sedmih letih približno 20 jezerskih zlatovščic, ki so se v tem času tudi uspešno namnožile, spremenilo nekoč bistro jezero $\mathrm{z}$ veliko živalskega planktona v jezero brez živalskega planktona in s povečano količino alg ob bregu. 


\section{TABELE}

Tabela 1: Morfometrične lastnosti, nadmorske višine ter trofično stanje jezer $\mathrm{v}$ Triglavskem narodnem parku (povzeto po Gams, 1962 in dopolnjeno z lastnimi opazovanji).

(O - oligotrofno, M- mezotrofno, E - eutrofno stanje $)^{*}$

\begin{tabular}{|l|c|c|c|c|c|}
\hline JEZERO & $\begin{array}{c}\text { nadmorska } \\
\text { višina }\end{array}$ & $\begin{array}{c}\text { srednja } \\
\text { površina }\end{array}$ & $\begin{array}{c}\text { največja } \\
\text { globina }\end{array}$ & $\begin{array}{c}\text { poznan } \\
\text { odtok }\end{array}$ & $\begin{array}{c}\text { trofično } \\
\text { stanje }\end{array}$ \\
\hline Zgornje Kriško jezero & $(\mathrm{m})$ & $(\mathrm{ha})$ & $(\mathrm{m})$ & & \\
\hline Rjavo jezero & 2150 & 0.62 & 9.5 & $\mathrm{da}$ & $\mathrm{O}$ \\
\hline Jezero pod Vršakom & 2000 & 1.20 & 10.2 & $\mathrm{da}$ & $\mathrm{O}$ \\
\hline Zeleno jezero & 1990 & 0.47 & 5.0 & - & $\mathrm{O}$ \\
\hline Srednje Kriško jezero & 1980 & 0.41 & 3.0 & - & $\mathrm{O}$ \\
\hline Spodnje Kriško jezero & 1950 & 0.35 & 8.5 & - & $\mathrm{O}$ \\
\hline Jezero v Ledvicah & 1880 & 0.80 & 7.5 & $\mathrm{da}$ & $\mathrm{M}$ \\
\hline Jezero v Lužnici & 1830 & 2.33 & 15.0 & $\mathrm{da}$ & $\mathrm{O}$ \\
\hline Dvojno jezero (5.) & 1800 & 0.75 & 9.5 & - & $\mathrm{M}$ \\
\hline Dvojno jezero (6.) & 1670 & 0.50 & 8.5 & $\mathrm{da}$ & $\mathrm{M}$ \\
\hline Jezero na Planini pri Jezeru & 1670 & 0.40 & 5.5 & - & $\mathrm{M}$ \\
\hline Krnsko jezero & 1430 & 1.76 & 10.0 & $\mathrm{da}$ & $\mathrm{E}$ \\
\hline Dupeljsko jezero & 1380 & 4.96 & 17.0 & $\mathrm{da}$ & $\mathrm{E}$ \\
\hline Črno jezero & 1340 & 0.44 & 3.6 & $\mathrm{da}$ & $\mathrm{O}$ \\
\hline
\end{tabular}

oligotrofno - malo dušikovih in fosforjevih spojin; eutrofno - veliko fosforjevih in dušikovih spojin 
Tabela 2: Vsebnost fosforjevih (tP) in dušikovih spojin ( $\mathrm{tN})$, prevodnost, alkaliteta, koncentracija klorofila ter biomasa zooplanktona $\mathrm{v}$ vodnem stolpcu $\mathrm{v} 14$ gorskih jezerih v Triglavskem narodnem parku ob koncu avgusta oz. v začetku septembra (povprečje za obdobje 1994 - 1998)

\begin{tabular}{|l|c|c|c|c|c|c|}
\hline JEZERO & tot $N$ & tot $P$ & alkaliteta & prevodnost & klorofil & zooplankton \\
\hline & $(\mathrm{mg} / \mathrm{l})$ & $(\mu \mathrm{g} / \mathrm{l})$ & $(\mu \mathrm{ekv} / \mathrm{l})$ & $(\mu \mathrm{S} / \mathrm{cm})$ & $(\mu \mathrm{g} / \mathrm{l})$ & $\left(\mathrm{g} / \mathrm{m}^{3}\right)$ \\
\hline Zgornje Kriško jezero & 0,69 & 23,61 & 1013 & 123,68 & 0,77 & 0,1549 \\
\hline Rjavo jezero & 1,10 & 18,08 & 1308 & 151,00 & 0,20 & 0,0957 \\
\hline Jezero pod Vršakom & 1,13 & 21,34 & 1234 & 135,24 & 1,50 & 0,0116 \\
\hline Zeleno jezero & 0,95 & 19,51 & 1340 & 147,38 & 0,57 & 0,2116 \\
\hline Srednje Kriško jezero & 0,76 & 24,48 & 1135 & 132,62 & 0,64 & 0,2134 \\
\hline Spodnje Kriško jezero & 0,83 & 23,45 & 1294 & 150,87 & 2,32 & 0,1007 \\
\hline Jezero v Ledvicah & 1,20 & 29,53 & 1511 & 167,85 & 0,69 & 0,1019 \\
\hline Jezero v Lužnici & 1,41 & 40,73 & 1719 & 199,15 & 3,52 & 0,1033 \\
\hline Dvojno jezero (5.) & 1,53 & 50,50 & 1587 & 177,05 & 2,29 & 0,3973 \\
\hline Dvojno jezero (6.) & 1,19 & 38,50 & 1588 & 171,60 & 1,58 & 0,0424 \\
\hline Jezero na Planini pri Jezeru & 2,21 & 181,17 & 2381 & 258,73 & 11,52 & 0,1015 \\
\hline Krnsko jezero & 0,96 & 27,63 & 1547 & 179,02 & 5,43 & 0,1118 \\
\hline Dupeljsko jezero & 1,19 & 29,60 & 1499 & 177,40 & 3,82 & 0,0010 \\
\hline Črno jezero & 1,12 & 15,21 & 1478 & 158,53 & 1,00 & 0,2088 \\
\hline
\end{tabular}

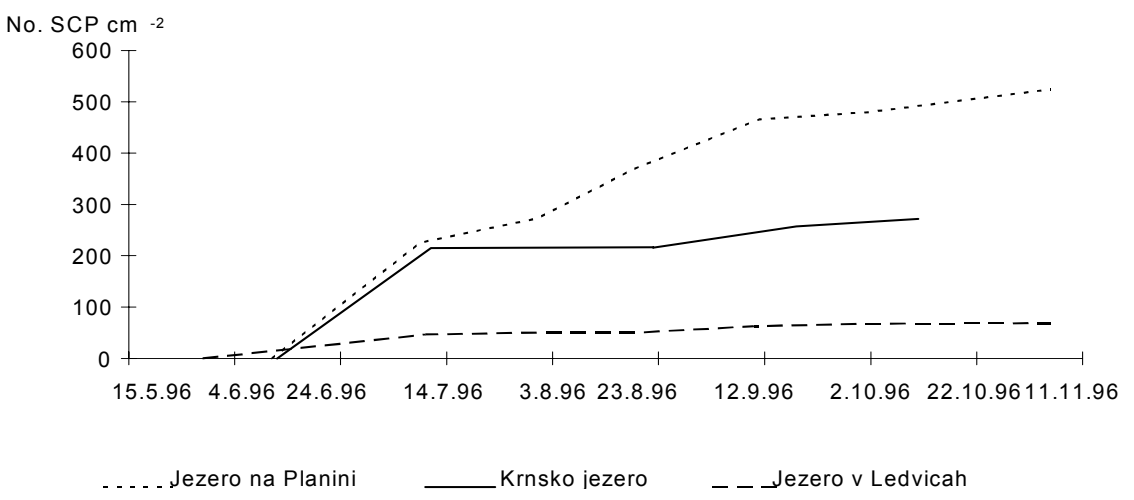




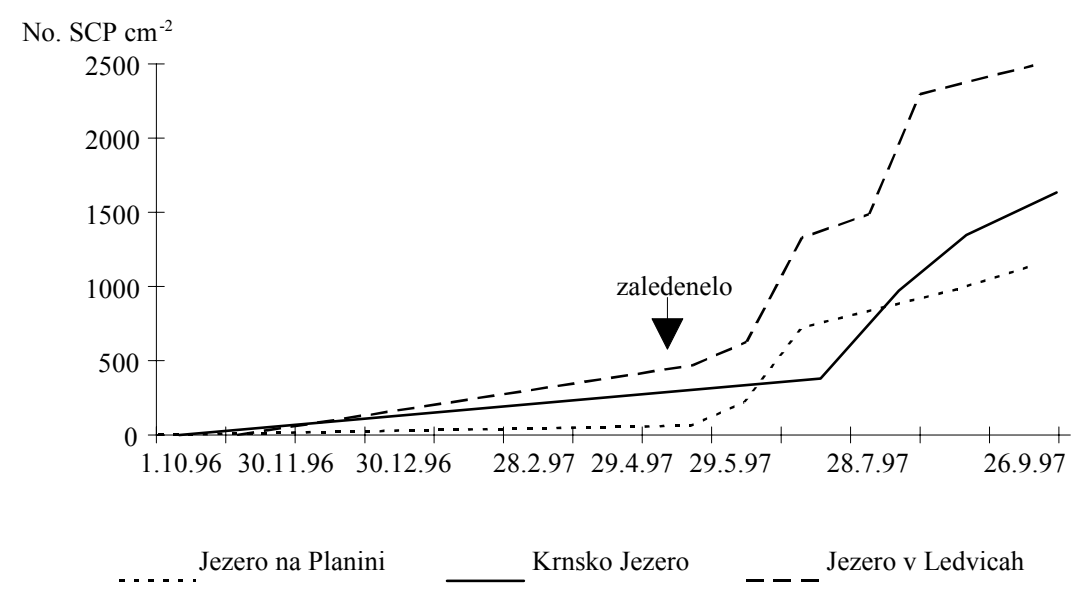

Slika 1: Kumulativne vrednosti koncentracij kroglastih ogljikovih delcev (SCP), izražene kot število delcev na kvadratni centimeter, $\mathrm{v}$ treh gorskih jezerih $\mathrm{v}$ letu 1996 (zgornja slika) in v letu 1997 (spodnja slika) (po Urbanc-Berčič in sod., 1998)

\section{SKLEPI}

Zaradi številnih človekovih dejavnosti, tako $\mathrm{v}$ neposredni bližini jezer kot tudi $\mathrm{v}$ njihovi širši okolici, so tudi naša visokogorska jezera doživela kvalitativne in kvantitativne spremembe, merljive s fizikalnimi, kemijskimi in biološkimi metodami. Te spremembe so bile zlasti intenzivne $\mathrm{v}$ zadnjih desetletjih, njihovi začetki pa segajo na začetek tega stoletja. Iz teh sprememb niso izvzeta niti najbolj odmaknjena in težko dostopna jezera, saj se določene snovi širijo $\mathrm{z}$ vetrovi. Zlasti kritično je stanje pri lahko dostopnih in množično obiskovanih jezerih. Tam se onesnaževanju iz zraka pridruži še neposredno onesnaževanje zaradi turizma (zlasti $\mathrm{v}$ obliki vnašanja mineralnih hranilnih snovi) ali zaradi povsem neosnovanih in neupravičenih poselitev rib v gorska jezera.

Po drugi strani pa so gorska jezera zelo občutljivi merilci za vse spremembe v okolju. So zelo majhna, združbe v njih so zelo enostavne in prav zaradi tega zelo občutljive. Življenjske združbe $\mathrm{v}$ njih so izpostavljene skrajnim in zahtevnim ekološkim razmeram, tako da jih vsak dodaten stres, ki prihaja od zunaj (navadno od človeka), spravi iz ravnotežja. Zaskrbljujoče je, da meritve in opazovanja kažejo, da je takih"iztirjenih" jezer vse več. Dosedanje raziskave moramo razumeti kot zgodnja 
opozorila, da lahko določene posledice omilimo, če jih že ne moremo preprečiti, a da se iz njih lahko tudi kaj naučimo za prihodnja ravnanja in posege $\mathrm{v}$ teh občutljivih ekosistemih.

\section{LITERATURA}

1. APHA, AWWA, WPCF, 1985: Standard methods for the examination of water and wastewater. 16th edition, 1268 str. Port City Press, Baltimore.

2. Batič F., 1996: Bioindication of stress in forest trees and forest ecosystems. Phyton 36 (3):15-25.

3. Brancelj A., Gaberščik A., Tome D., Urbanc-Berčič O., Šiško M., Jerebic A., Smodiš B., Jeran Z., Lojen S., Jačimovič R., Novak J., Culiberg M., Ogrin D., 1998: Slovenska alpska jezera: paleoekologija in ekologija (SLO-ALPE): Procesi eutrofizacije $\mathrm{v}$ visokogorskih jezerih (fazno poročilo o rezultatih opravljenega znanstveno-raziskovalnega dela na področju temeljnega raziskovanja). Ljubljana: Inštitut za biologijo Ljubljana, Inštitut Jožef Štefan, ZRC SAZU, Filozofska fakulteta, 1998:30.

4. Brancelj A., 1995: Mit o kristalno čistih visokogorskih jezerih Julijcev se je dokončno podrl. Delo - Znanje za razvoj, 7.6.1995.

5. Brancelj A., 1997: Slovenska visokogorska jezera ogroža (tudi) naseljevanje rib. Delo - Znanost, 13.8.1997

6. Brancelj A., Kosi G., Šiško M., 1997: Distribution of algae and crustacea (Copepoda \& Cladocera) in mountain lakes in Slovenia with different trophic levels. Periodicum Biologorum: 99(1):87-96.

7. Brancelj A., Urbanc-Berčič O., Krušnik C., Kosi G., Povž M., Dobravec J., 1995: Življenje v vodah Triglavskega narodenga parka. ed. J. Dobravec. Strokovna knjižnica Triglavskega narodenga parka: Razprave in raziskave 4.

8. Bricelj M., Brancelj A., Vrhovšek D., Krušnik C., Žerdin M., Rekar-Remec Š., Šiško M., Blejec A., Krevs M., Dobravec J., Ferjančič A., Stanič K., Kafol T., Mrvar M., 1991: Izvajanje programa Limnološke postaje Bled 1991. Naročnik: Ministrstvo za varstvo okolja in urejanje prostora, Ljubljana.

9. Gaberščik A., Urbanc-Berčič O., Brancelj A., Šiško M., 1997: Mountain lakes remote but endangered. Proceedings, 1st international conference on environmental restoration, Ljubljana, July 6-9. 1997

10. Gams I., 1962: Visokogorska jezera v Sloveniji (gradivo). Geografski zbornik 7: 195-262.

11. Grimault J., O., Boyle J., Appleby P. G., Rose N. L., 1997: Evidence for atmospheric contamination from lake sediment analyses. v AL:PE Acidification of mountain lakes: Paleolimnology and Ecology, Part 2 : Remote mountain lakes as indicators of air pollution and climate change. 
12. Jeran Z., Batič F., Byrne A. R., Benedik L., Stegnar P., 1991: Uranium levels in transplanted lichens around the uranium mine at Žirovski vrh. III. ItalianYugoslav Symposium Low Level Radiation (eds.: Horvat, Stegnar) - Ljubljana; Institut "Jožef Stefan", 1991.- Str.169-173.

13. Urbanc-Berčič O, Brancelj A, Šiško M., 1998: Carbonaceous particles from sediment traps in mountain lakes of the Triglav National Park, Slovenia. In: Internatonial conference on water protection in national parks and other protected areas; 1998 May 20-23; Primošten. Primošten: Republic of Croatia Ministry of physical plannig, building and housing, 1998; 1-8.

14. Wathne B., 1992: Acidification of mountain lakes: paleolimnology and ecology. The AL:PE project. Documenta dell' Istituto Italiano di Idrobiologia dott. Marco de Marchi 32: 7-22.

\section{MOUNTAIN LAKES POLLUTION}

\section{Summary}

Within the area of Triglav National Park, which covers most of the Julian Alps (NW Slovenia), there are fourteen mountain lakes. They are aggregated into three groups: three lakes in the group of Kriška Jezera, three lakes in the group of Krnska Jezera and eight lakes in the Valley of Seven Triglav Lakes (Dolina sedmerih triglavskih jezer) which includes also lake Jezero na Planini pri Jezeru.

First systematic survey of mountain lakes in Julian Alps dated back into 1990. In that year physical, chemical and biological analyses were done in eight lakes in the Valey of Seven Triglav Lakes. The aim of those survey was to assess the quality of water and biota in the lakes and to qualify and quantify the extend of their pollution. From 1991 onward we included into monitoring program all mountain lakes. Intensive monitoring program as well as scientific research program are still running.

Mountain lakes were exposed to very changeble weather conditions within last eight years, thus only long-lasting measurements and observations could get an answer about their status. Lakes in Julian Alps are small and thus under intensive influence of weather conditions. To get better insight into the lake's status we analysed sediment from some lakes. Physical, chemical and biological analyses of the sediment allowed us to reconstruct activities within the lake and in its vicinity within time span of up to 200 years.

Quality of water in mountain lakes depends on three types of human activities:

- $\quad$ input of poisonous or harmfull materials 
- input of mineral nutrients (mainly nutrogen and phosphorus compounds)

- $\quad$ change of communities by fish introduction

Poisonous or harmfull materials, including radioactive outfall, are transported into the lakes by winds and rain, often from long distances. Wind direction and quantity of precpitation are the main factors on quality and qantity of input. Very rare are direct inputs, like spills, into the lakes. Nutrients, mainly nutrogen and phosphorus compounds, increase eutrophication of the lakes. Intensive algal growth and depletion of oxygen in near-bottom strata are the most common effects. The main sources of nutrients input are tourism and agriculture in the vicinity of those lakes. Introduction of fish into mountain lakes is specific problem with very serious effects on lakes' ecosystem. Usually it is connected with rapid eutrophication, associated with algal blooms and depletion of oxygenas (as for example lake Jezero Na Planini Pri Jezeru, lake Krnsko Jezera and lake Dvojno Jezero).

All above mentioned human activities turned some previous pristine mountain lakes into heavily polluted ones. Some of them are comparable to heavy eutrophicated lowland lakes. 